\title{
Development of a synthetic medium for continuous anaerobic growth and ethanol production with a lactate dehydrogenase mutant of Bacillus stearothermophilus
}

\author{
Ricardo San Martin, $†$ Des Bushell, David J. Leak* and Brian S. Hartley \\ Centre for Biotechnology, Imperial College of Science, Technology and Medicine, London SW7 2AZ, UK
}

(Received 12 September 1991; revised 20 December 1991; accepted 3 February 1992)

\begin{abstract}
A synthetic medium was developed by the pulse and medium-shift technique for the continuous cultivation of Bacillus stearothermophilus strain LLD-15 (NCIMB 12428) under anaerobic conditions. This mutant strain lacks L-lactate dehydrogenase activity, and is a promising candidate for the production of ethanol from pentoses and hexoses, using a high-temperature two-stage process. The final medium contained four amino acids and five vitamins, and growth characteristics in this medium compared well with those in complex medium containing yeast extract and tryptone. At $70^{\circ} \mathrm{C}$, the medium was capable of supporting good anaerobic and aerobic growth at $10 \mathrm{~g}$ input sucrose $\mathrm{I}^{-1}$. High ethanol production indicated that pyruvate metabolism probably occurred via the combined activity of the pyruvate-formate-lyase pathway and pyruvate dehydrogenase.
\end{abstract}

\section{Introduction}

Over the past 15 years there has been considerable interest in the use of thermophilic bacteria for the production of ethanol from lignocellulosic materials. These micro-organisms offer important advantages over traditional processes based on Saccharomyces cerevisiae, such as the ability to ferment a wider range of substrates including hemicellulose-derived pentoses, lower ethanol separation costs and reduction of ethanol inhibition by continuous product removal using mild vacuum or gas sparging.

Table 1 shows the most promising ethanologenic thermophilic bacteria studied in recent years. Microorganisms such as Thermoanaerobacter ethanolicus and Clostridium thermohydrosulfuricum apparently give ethanol yields comparable to those of yeasts $[1.8-1.9 \mathrm{~mol}$ (mol fermented glucose) $)^{-1}$, but in all cases cultivation conditions have considered low substrate concentrations, use of large amounts of complex medium supplements and small process volumes. Most attempts to establish continuous cultures have resulted in poor growth and low ethanol yields.

* Author for correspondence. Tel. (071) 5895111 , ext. 7090; fax (071) 2258942.

† Present address: Universidad Católica, Departmento de Ingeniería Química, Vicuña Mackenna 4860, Casilla 6177, Santiago, Chile.
We have concentrated on a Bacillus stearothermophilus strain LLD-R (NCIMB 12403) selected for its ability to grow rapidly at $70^{\circ} \mathrm{C}$, both aerobically and anaerobically, on a wide range of sugars (Hartley \& Shama, 1987; Amartey et al., 1991), including pentoses (e.g. xylose). Under anaerobic conditions, it produces primarily L-lactate via an NADH-linked lactate dehydrogenase, as well as minor amounts of formate, acetate and ethanol via the pyruvate-formate-lyase pathway (PFL). By inactivating the L-lactate dehydrogenase (mutant strain LLD-15; NCIMB 12428), it was possible to increase the production of ethanol, formate and acetate owing to a higher flux of pyruvate through the PFL pathway (Payton \& Hartley, 1985). Moreover, under certain growth conditions (e.g. low $\mathrm{pH}$, high sugar concentration), the ethanol yields of strain LLD-15 exceed those predicted by the PFL balance, suggesting the operation of a second anaerobic pathway for conversion of pyruvate to ethanol. $\mathrm{High} \mathrm{CO}_{2}$ production and the absence of formate dehydrogenase and formatehydrogen lyase suggested the anaerobic operation of pyruvate dehydrogenase (PDH), which was subsequently confirmed by the demonstration of high enzyme activities (Hartley \& Shama, 1987).

Under conditions that maximize ethanol production, strain LLD-15 grows poorly, limiting the application of conventional continuous culture. To overcome this problem, Hartley (1987) proposed a two-stage process in 
Table 1. Fermentation conditions, media used and ethanol yields

All media included essential mineral salts, with some also incorporating trace elements and vitamin supplements.

\begin{tabular}{|c|c|c|c|c|c|}
\hline Micro-organism & $\begin{array}{c}\text { Fermentation } \\
\text { mode }\end{array}$ & $\begin{array}{c}\text { Glucose } \\
\left(\mathrm{g} \mathrm{l}^{-1}\right)\end{array}$ & $\begin{array}{l}\text { Yeast } \\
\text { extract } \\
\left(\mathrm{g} \mathrm{l}^{-1}\right)\end{array}$ & $Y_{\mathrm{p} / \mathrm{s}}^{*}$ & Reference \\
\hline \multicolumn{6}{|l|}{$\begin{array}{l}\text { Clostridium } \\
\text { thermohydrosulfuricum } \\
\text { Strain JW } 102\end{array}$} \\
\hline & Batch & 5 & $\begin{array}{r}5 \\
20\end{array}$ & $\begin{array}{l}1.07 \\
1.40\end{array}$ & Wiegel et al (1979) \\
\hline Strain $39 \mathrm{E}$ & Test tubes & 5 & $3 \dagger$ & 1.95 & $\mathrm{Ng}$ et al. (1981) \\
\hline $\begin{array}{l}\text { Thermoanaerobium } \\
\text { brockii }\end{array}$ & Test tubes & $3 \cdot 5$ & $\begin{array}{l}0.5 \\
1\end{array}$ & $\begin{array}{l}0.94 \\
0.65\end{array}$ & Lamed \& Zeikus (1980) \\
\hline & Batch & 5 & 3 & $<0.3$ & \\
\hline & Continuous & 15 & 9 & - & Sonnleitner et al. (1984) \\
\hline $\begin{array}{l}\text { Thermoanaerobacter } \\
\text { ethanolicus }\end{array}$ & $\begin{array}{l}\text { Test tubes } \\
\text { Batch }\end{array}$ & $\begin{array}{r}8 \\
10 \\
20\end{array}$ & $\begin{array}{c}5 \\
7 \cdot 5 \\
15\end{array}$ & $\begin{array}{l}1 \cdot 80 \\
0 \cdot 75 \\
1 \cdot 72 \ddagger\end{array}$ & $\begin{array}{l}\text { Wiegel \& Ljungdahl (1981) } \\
\text { Kaanan \& Mutharasan (1984) }\end{array}$ \\
\hline $\begin{array}{l}\text { Clostridium } \\
\text { thermosaccharolyticum } \\
\text { strain IMG } 6544\end{array}$ & Batch & 5 & $3+$ & 0.96 & Vancanneyt et al. (1987) \\
\hline
\end{tabular}

* $Y_{\mathrm{p} / \mathrm{s}}=$ mol ethanol (mol fermented glucose) $)^{-1}$.

$\dagger$ Medium also included $10 \mathrm{~g}$ tryptone $1^{-1}$.

$\ddagger$ Only $22 \%$ of the glucose was consumed.

which continuous anaerobic operation is maintained by a constant supply of aerobic cells. To be able to study exact material balances in this process, a completely defined medium was desirable, capable of supporting maximum aerobic and anaerobic growth of strain LLD15 in continuous culture. Recently Amartey et al. (1991) reported a defined medium BST-MM, containing methionine, biotin, thiamin and nicotinic acid, for the aerobic cultivation of this strain on $5 \mathrm{~g}$ sucrose $\mathrm{l}^{-1}$ at $70^{\circ} \mathrm{C}$. However, supplementation with small amounts of yeast extract and tryptone (BST-SDLM) was required to obtain reasonable growth under anaerobic conditions, suggesting that the aerobic and anaerobic growth requirements of strain LLD-15 are different.

This work describes the development of a completely defined synthetic medium capable of sustaining good anaerobic growth in continuous culture, by replacement of yeast extract and tryptone with a mixture of amino acids and vitamins using the pulse and medium-shift technique (Kuhn et al., 1979; Goldberg \& Er-Al, 1981).

\section{Methods}

Bacterial strains. All experiments were started with cultures of Bacillus stearothermophilus strain LLD-15(NCIMB 12428), maintained at $-18^{\circ} \mathrm{C}$ in glycerol $\left(1 \mathrm{ml}\right.$ culture, $0.8 \mathrm{ml}$ of 0.81 glycerol $\left.\mathrm{l}^{-1}\right)$, as recommended by Brock (1978). B. stearothermophilus strain LLD-R, (NCIMB 12403) is a revertant of the L-lactate dehydrogenase mutation selected in continuous culture of strain LLD-15 (Amartey, 1988).

Medium salts and carbon source. The composition of the medium salts used in all experiments was $\left(\mathrm{mg} \mathrm{l}^{-1}\right)$ : citric acid, $320 ; \mathrm{MgSO}_{4} \cdot 7 \mathrm{H}_{2} \mathrm{O}$, $270 ; \quad \mathrm{Na}_{2} \mathrm{HPO}_{4} .2 \mathrm{H}_{2} \mathrm{O}, \quad 125 ; \quad \mathrm{K}_{2} \mathrm{SO}_{4}, \quad 1300 ; \quad \mathrm{NH}_{4} \mathrm{Cl}, 2000$; $\mathrm{CaCl}_{2} .2 \mathrm{H}_{2} \mathrm{O}, 2.5 ; \mathrm{MnCl}_{2} .4 \mathrm{H}_{2} \mathrm{O}, 3.0 ; 0.25 \mathrm{ml}$ trace element solution $1^{-1}$. The composition of the trace element solution was $\left(\mathrm{mg} \mathrm{l}^{-1}\right)$ : $\mathrm{ZnSO}_{4} . \mathrm{H}_{2} \mathrm{O}, 320 ; \mathrm{H}_{3} \mathrm{BO}_{3}, 80 ; \mathrm{CoCl}_{2} .6 \mathrm{H}_{2} \mathrm{O}, 400 ; \mathrm{CuSO}_{4} .5 \mathrm{H}_{2} \mathrm{O}$, $1600 ; \mathrm{NiCl}_{2} .6 \mathrm{H}_{2} \mathrm{O}, 80 ; \mathrm{FeCl}_{3} .6 \mathrm{H}_{2} \mathrm{O}, 4300$; EDTA, 2000. Sucrose was used as carbon source at $10 \mathrm{~g} \mathrm{l}^{-1}$.

In experiments with complex medium, salts, yeast extract and tryptone were sterilized together at $121^{\circ} \mathrm{C}$ for $1 \mathrm{~h}$ in 201 reservoirs: When using a synthetic medium, the salt solution was sterilized separately and after cooling to room temperature, the amino acids and vitamins were added using $\mathbf{0} \cdot 2 \mu \mathrm{m}$ sterile filters (Gelman Sciences). In all cases, sucrose was autoclaved separately.

All amino acids and vitamins were 'cell culture tested' grade (Sigma). Each amino acid was dissolved separately and filter-sterilized before being added to the basic salt medium. In the case of methionine and isoleucine, it was necesssary to heat to approximately $50^{\circ} \mathrm{C}$ to achieve complete dissolution. All of the vitamins were dissolved together in approximately $100 \mathrm{ml}$ of distilled water, and filter-sterilized.

Inoculum development and continuous culture start-up procedure. Inocula were prepared at $70^{\circ} \mathrm{C}$ in $500 \mathrm{ml}$ Erlenmeyer flasks $(275$ r.p.m.) containing $100 \mathrm{ml}$ of the complex medium used in the bioreactor (see below). The buffering capacity was increased by increasing the $\mathrm{Na}_{2} \mathrm{HPO}_{4} \cdot 2 \mathrm{H}_{2} \mathrm{O}$ concentration from $0.125 \mathrm{~g} \mathrm{l}^{-1}$ to $2.5 \mathrm{~g}$ $\mathrm{I}^{-1}$, to prevent the $\mathrm{pH}$ from falling below 6.0-6.2, since this caused rapid cell lysis. The bioreactor was inoculated with $200 \mathrm{ml}$ of the exponentially growing culture under aseptic conditions. 
After inoculation, the cells were allowed to adapt and attain exponential growth. The feed pump was then started to give a low dilution rate $\left(0 \cdot 1 \mathrm{~h}^{-1}\right)$. Stable growth at higher dilution rates was achieved by gradual increments in dilution rate $\left(0.05 \mathrm{~h}^{-1}\right.$ per change). Steady state conditions were determined by periodic analysis of biomass in the bioreactor. Normally, steady state was attained after 3-5 retention times following a change in conditions.

Continuous cultures. All experiments used a LSL Biolafitte 21 Bioreactor (Life Science Laboratories) with a 1.51 working volume, equipped with automatic control of temperature, foam and $\mathrm{pH}$. Temperature was controlled at $70 \pm 0.3^{\circ} \mathrm{C}$ using the water-jacket of the bioreactor and $\mathrm{pH}$ was controlled to within $\pm 0.05 \mathrm{pH}$ units with $250 \mathrm{~g}$ $1^{-1} \mathrm{KOH}$. The life of the autoclavable $\mathrm{pH}$ probes (Ingold Messtechnik AG) was reduced by the severity of the sterilization procedure $\left(121^{\circ} \mathrm{C}\right.$, $1 \mathrm{~h})$ required to prevent possible contamination with spores of other strains. For this reason, the bioreactor was initially autoclaved separately for $1 \mathrm{~h}$, then for a further $25 \mathrm{~min}$ with the $\mathrm{pH}$ probe installed. Drifting of the $\mathrm{pH}$ set-point with prolonged operation times was minimized by checking samples every $5 \mathrm{~h}$ with a bench $\mathrm{pH}$ meter and recalibrating appropriately. To prevent degradation of medium components, the bioreactor was autoclaved with water in it.

Foaming was controlled automatically by addition of 0.21 aqueous Dow Corning 1510 silicone antifoam $\mathrm{l}^{-1}$ (BDH). Incoming gases were passed through hydrophobic $0.2 \mu \mathrm{m}$ filters (Acro 50, Gelman Sciences). The flow rates were measured under standard conditions using precision gas flowmeters (model RS 2, Meterate, Glass Precision Engineering). Anaerobic conditions were maintained by sparging with approximately $50 \mathrm{ml}$ nitrogen $\mathrm{min}^{-1}$. Agitation was kept constant at 400 r.p.m.

To prevent gas exit via the overflow system, the bioreactor level was kept constant by continuous removal of the broth using a peristaltic pump activated by a level controller system. The output gases were passed through a vertical stainless steel condenser located on top of the bioreactor, maintained at between -2 and $-5^{\circ} \mathrm{C}$ using 0.41 ethylene glycol $1^{-1}$ in a Grant FC 25 chiller and FH 15A heater/circulator in combination (Grant Instruments). The gases were then filtered through $0.3 \mu \mathrm{m}$ filters (Gamma 12, Whatman International) and dried by passing through a tube of anhydrous calcium sulphate (W. A. Hammond Drierite Company) before being passed to the mass spectrometer (SX200F Quadrupole, VG Gas Analysis) for analysis or discharged to the atmosphere.

The flow rate of medium into the bioreactor was controlled with a Watson Marlow 301 pump and measured by diverting the flow through a $10 \mathrm{ml}$ pipette and timing the passage of a fixed volume. Samples from the bioreactor were obtained in duplicate using $30 \mathrm{ml}$ sterile capped bottles (Sterilin). The whole broth was used for $\mathrm{pH}$ and optical density measurements. Culture supernatants were obtained by centrifugation at $25000 \mathrm{~g}\left(20 \mathrm{~min}, 5^{\circ} \mathrm{C}\right)$ in a Sorval RC-5B refrigerated centrifuge equipped with a SS-34 rotor (Du Pont Instruments), and stored at $-20^{\circ} \mathrm{C}$ for further analysis.

General procedure for the development of the synthetic medium. The procedure used to develop the synthetic medium consisted of three stages: (1) determination of the minimum requirements of yeast extract and/or tryptone; (2) formulation of a synthetic medium to replace the complex components; and (3) removal of non-essential amino acids and vitamins using the pulse and medium-shift technique.

Strain LLD-15 was initially cultivated anaerobically in continuous culture $\left(D=0.1 \mathrm{~h}^{-1}\right)$, in a complex medium containing $10 \mathrm{~g}$ sucrose $\mathrm{l}^{-1}$, $2 \mathrm{~g}$ yeast extract $^{-1}$ (Difco) and $2 \mathrm{~g}$ tryptone $1^{-1}$ (Oxoid). This medium was tested at different dilution rates and tryptone was then removed to determine if all the growth factors required by LLD- 15 were present in the yeast extract. Once this was established, the amount of yeast extract was reduced to determine the minimum required for growth.

Yeast extract was then replaced by a synthetic medium containing 18 amino acids and five vitamins (medium BST-defined). The concentrations were based on the approximate composition of commercial yeast extracts and previous synthetic media developed for aerobic cultivation of B. stearothermophilus NCA-1503 (Rowe et al., 1975). A batch experiment using this medium proved that it was suitable for the anaerobic cultivation of strain LLD-15.

Finally, identification of the essential amino acids and vitamins was performed using the pulse and medium-shift technique of Kuhn et al. (1979). The procedure required establishment of a carbon-limited continuous culture, using a defined medium that contained 18 amino acids and five vitamins. Once steady state was attained, the amino acid concentrations in the incoming medium were reduced to $50 \%$ of their original value. If the cell density decreased substantially as a result of dilution of an essential amino acid to a level where it had become the growth limiting nutrient, amino acids $\left(20 \mathrm{ml}\right.$ at $\left.7.5 \mathrm{mg} \mathrm{ml}^{-1}\right)$ were injected sequentially into the bioreactor. When a significant response in biomass and residual sucrose concentration was detected (usually within 3-4 h), a new medium was prepared with increased concentrations (150 $\left.\mathrm{mg} \mathrm{l}^{-1}\right)$ of the corresponding amino acid(s) and a new twofold dilution of the remaining amino acids. The concentrations of amino acids added during the 'pulse' should have been sufficient for the cell density and sucrose concentrations to return to their values before medium dilution. However, as a reduced response could result from the dilution of more than one essential amino acid below its critical concentration, $20 \%$ of this response was usually taken to be significant, assuming that the response comprised an increase in cell density accompanied by a proportional decrease in residual sucrose concentration. The procedure was repeated until all non-essential amino acids had been removed from the medium.

Although this medium development procedure should ideally have been done at a higher dilution rate $\left(0.5 \mu_{\max }\right.$ is recommended) a dilution rate of $0 \cdot 1 \mathrm{~h}^{-1}$ was used in this case to minimize the problems of reversion when growth was limited by nutrients other than sucrose, which was exacerbated at higher dilution rates.

Analysis. Biomass was routinely estimated from the $\mathrm{OD}_{600}$ (Novaspec 4049 spectrophotometer, LKB). The biomass concentration was calculated using a calibration curve of $\mathrm{OD}_{600}$ vs cell dry weight in $\mathrm{g}^{-1}$ (one $\mathrm{OD}$ unit corresponded to $0.35 \mathrm{~g} \mathrm{t}^{-1}$ ). Cell dry weights were determined in triplicate by centrifuging samples at $25000 \mathrm{~g}(20 \mathrm{~min}$, $5{ }^{\circ} \mathrm{C}$ ). The cell pellet was washed with distilled water and centrifuged, and the resulting pellet dried at $70^{\circ} \mathrm{C}$ to constant weight $(48 \mathrm{~h})$.

Sucrose was determined by the phenol/sulphuric acid method of Dubois et al. (1956).

Ethanol was analysed by gas chromatography (Philips PU 4500, Philips Scientific) using a flame ionization detector and a Poropak $Q$ column. The column temperature was maintained at $180^{\circ} \mathrm{C}$, and the injector and detector temperatures were set at 230 and $250^{\circ} \mathrm{C}$, respectively. Nitrogen was used as the carrier gas, with a flow rate of $40 \mathrm{ml} \mathrm{min}^{-1}$. An ethanol solution $\left[1-5 \mathrm{ml}\right.$ (1 water) $^{-1}$ was used as the

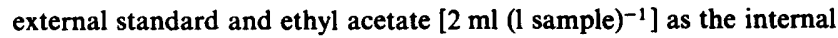
standard. The amount injected was $1 \mu$ l. Peak areas were measured on a programmable integrator (Chromatopac C-R3A, Shimadzu).

The ethanol values reported in this work refer to aqueous ethanol, i.e. the amount of ethanol detected in the broth. No corrections were made for the amount of ethanol lost in the vapour phase. However, all experiments were performed under the same conditions (i.e. nitrogen, flow, agitation, temperature), to allow direct comparison.

Formate, acetate, pyruvate and succinate were determined by gas chromatography of their methyl esters using the method of Drummond \& Shama (1982). $1 \mu \mathrm{l}$ of the chloroform layer was injected onto a column of $10 \%$ DEGA, $2 \% \mathrm{H}_{3} \mathrm{PO}_{4}$ on Diatomite $\mathrm{C} 100 / 120$ mesh. The column was initially maintained at $50^{\circ} \mathrm{C}$ for $1 \mathrm{~min}$ and then heated to $130{ }^{\circ} \mathrm{C}$ at a rate of $16^{\circ} \mathrm{C} \mathrm{min}{ }^{-1}$. The final temperature was maintained at $130^{\circ} \mathrm{C}$ for $18 \mathrm{~min}$. The injector and detector temperatures were set 
Table 2. Anaerobic cultivation of B. stearothermophilus strain LLD-15 at $70^{\circ} \mathrm{C}$ on complex medium

Medium composition: $10 \mathrm{~g}$ input sucrose $\mathrm{l}^{-1} ; 2 \mathrm{~g}$ yeast extract $\mathrm{l}^{-1} ; 2 \mathrm{~g}$ tryptone $\mathrm{1}^{-1} ; \mathrm{pH} 7 \cdot 0$.

\begin{tabular}{|c|c|c|c|c|c|c|c|c|c|c|c|}
\hline \multirow{2}{*}{$\begin{array}{c}D \\
\left(h^{-1}\right)\end{array}$} & \multicolumn{2}{|c|}{ Sucrose $\left(\mathrm{g} \mathrm{l}^{-1}\right)^{*}$} & \multirow{2}{*}{$\begin{array}{c}\text { Sucrose } \\
\text { consumed }(\%)\end{array}$} & \multirow{2}{*}{$\begin{array}{l}\text { Cells } \\
\left(\mathrm{g} \mathrm{I}^{-1}\right)\end{array}$} & \multirow[b]{2}{*}{$Y_{x / 3} t$} & \multirow{2}{*}{$\begin{array}{c}\text { Specific consumption } \\
\text { [g sucrose }(\mathrm{g} \text { cells) })^{-1} \mathrm{~h}^{-1} \text { ] }\end{array}$} & \multicolumn{2}{|c|}{ Ethanol } & \multirow[b]{2}{*}{$Y_{p / s t} t$} & \multirow{2}{*}{$\begin{array}{l}\text { Volumetric productivity } \\
\left(\mathrm{g} \text { ethanol } 1^{-1} \mathrm{~h}^{-1}\right)\end{array}$} & \multirow{2}{*}{$\begin{array}{l}\text { Specific productivity } \\
\text { [g ethanol (g cells) })^{-1} \mathrm{~h}^{-1} \text { ] }\end{array}$} \\
\hline & $S_{0}$ & $\mathbf{S}_{1}$ & & & & & $\left(\mathrm{~g} \mathrm{1}^{-1}\right)$ & $\left(\mathrm{mmol} \mathrm{1}^{-1}\right)$ & & & \\
\hline $\begin{array}{l}0.1 \\
0.2 \\
0.3\end{array}$ & $\begin{array}{l}10 \cdot 3 \\
12 \cdot 4 \\
11 \cdot 3\end{array}$ & $\begin{array}{l}0.41 \\
0.62 \\
0.79\end{array}$ & $\begin{array}{l}96.0 \\
95 \cdot 1 \\
93.0\end{array}$ & $\begin{array}{l}0.56 \\
0.70 \\
0.95\end{array}$ & $\begin{array}{l}0.057 \\
0.059 \\
0.090\end{array}$ & $\begin{array}{l}1.8 \\
3.4 \\
3.3\end{array}$ & $\begin{array}{l}1.05 \\
1.15 \\
1.19\end{array}$ & $\begin{array}{l}22 \cdot 8 \\
24 \cdot 6 \\
25 \cdot 8\end{array}$ & $\begin{array}{l}0.7 \\
0.8 \\
0.8\end{array}$ & $\begin{array}{l}0.11 \\
0.23 \\
0.36\end{array}$ & $\begin{array}{l}0.19 \\
0.33 \\
0.38\end{array}$ \\
\hline
\end{tabular}

$* \mathrm{~S}_{0}$, sucrose concentration in incoming medium; $S_{1}$, residual sucrose concentration in bioreactor.

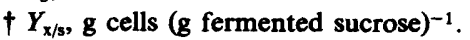

$\ddagger Y_{\mathrm{p} / \mathrm{s}}$, mol ethanol (mol fermented sucrose) $)^{-1}$

Table 3. Anaerobic cultivation of B. stearothermophilus LLD-15 at $70^{\circ} \mathrm{C}$ on complex medium without tryptone

Medium composition: $10 \mathrm{~g}$ input sucrose $1^{-1} ; 2 \mathrm{~g}$ yeast extract $1^{-1} ; \mathrm{pH} 7 \cdot 0$. At $D=0 \cdot 3 \mathrm{~h}^{-1}$, lactate production indicates take-over by revertant strain LLD-R.

\begin{tabular}{|c|c|c|c|c|c|c|c|c|c|c|c|c|}
\hline \multirow{2}{*}{$\begin{array}{c}D \\
\left(h^{-1}\right)\end{array}$} & \multicolumn{2}{|c|}{ Sucrose $\left(\mathrm{g}^{-1}\right)^{*}$} & \multirow{2}{*}{$\begin{array}{c}\text { Sucrose } \\
\text { consumed }(\%)\end{array}$} & \multirow{2}{*}{$\begin{array}{l}\text { Cells } \\
\left(\mathrm{g}^{-1}\right)\end{array}$} & \multirow[b]{2}{*}{$\boldsymbol{r}_{\mathrm{x} / \mathrm{s}} \boldsymbol{t}$} & \multirow[b]{2}{*}{$Y_{1 / 3} \ddagger$} & \multirow{2}{*}{$\begin{array}{l}\text { Specific consumption } \\
\text { [g sucrose }(\mathrm{g} \text { cells })^{-1} \mathrm{~h}^{-1} \text { ] }\end{array}$} & \multicolumn{2}{|c|}{ Ethanol } & \multirow[b]{2}{*}{$\boldsymbol{Y}_{\mathrm{p} / \boldsymbol{s}} \S$} & \multirow{2}{*}{$\begin{array}{l}\text { Volumetric productivity } \\
\left(\mathrm{g} \text { ethanol } \mathrm{1}^{-1} \mathrm{~h}^{-1}\right)\end{array}$} & \multirow{2}{*}{$\begin{array}{c}\text { Specific productivity } \\
{\left[\mathrm{g} \text { ethanol (g cells) }{ }^{-1} \mathrm{~h}^{-1}\right]}\end{array}$} \\
\hline & $\mathbf{S}_{0}$ & $\mathbf{S}_{1}$ & & & & & & $\left(\mathrm{~g} \mathrm{l}^{-1}\right)$ & $\left(\mathrm{mmol} \mathrm{l}^{-1}\right)$ & & & \\
\hline $0 \cdot 15$ & $11 \cdot 3$ & 0.72 & 93.6 & 0.53 & 0.050 & - & $3 \cdot 0$ & 1.99 & $43 \cdot 3$ & 1.4 & $0 \cdot 30$ & 0.56 \\
\hline 0.20 & $12 \cdot 1$ & 1.0 & 91.6 & 0.58 & 0.052 & - & 3.8 & $2 \cdot 24$ & $48 \cdot 8$ & 1.5 & 0.45 & 0.77 \\
\hline $0 \cdot 30$ & $12 \cdot 2$ & 0.44 & 96.4 & 0.55 & 0.047 & 1.9 & $6 \cdot 4$ & 1.59 & $34 \cdot 5$ & 1.0 & 0.48 & 0.87 \\
\hline 0.50 & $12 \cdot 2$ & $3 \cdot 38$ & $72 \cdot 4$ & 0.46 & 0.052 & $2 \cdot 7$ & 9.6 & 0.48 & $10 \cdot 4$ & 0.4 & 0.24 & 0.52 \\
\hline
\end{tabular}

* $S_{0}$, sucrose concentration in incoming medium; $S_{1}$, residual sucrose concentration in bioreactor.

$\dagger Y_{\mathrm{x} / \mathrm{s}}$, g cells (g fermented sucrose) $)^{-1}$.

$\ddagger Y_{1 / s}$, mol lactate (mol fermented sucrose) $)^{-1}$.

$\S Y_{\mathrm{p} / \mathrm{s}}$, mol ethanol (mol fermented sucrose) $)^{-1}$

up at $230^{\circ} \mathrm{C}$ and $250^{\circ} \mathrm{C}$, respectively. The carrier gas was nitrogen at $40 \mathrm{ml} \mathrm{min}{ }^{-1}$. Peak areas were measured using a programmable integrator (Chromatopac C-R3A, Shimadzu).

L-Lactate was determined enzymically, using a commercial kit (Sigma).

Reproducibility of results. All chemical analyses were done in duplicate and are presented as the mean values. Much of the continuous culture work was repeated at least once to confirm the trends obtained. However, the results presented here are those from representative runs.

\section{Results and Discussion}

Determining the minimum amounts of yeast extract and tryptone required for growth of $L L D-15$

Strain LLD-15 was initially cultivated anaerobically in a medium containing $2 \mathrm{~g}$ yeast extract $\mathrm{l}^{-1}$ and $2 \mathrm{~g}$ tryptone $1^{-1}$. The objective of these experiments was to determine the minimum levels of complex nutrients required for adequate growth. Table 2 shows that greater than $90 \%$ of the sucrose could be consumed up to $D=0.3 \mathrm{~h}^{-1}$. Above this dilution rate, sucrose utilization and cell density dropped significantly, while small amounts of lactate were detected in the broth. Lactate production is discussed in more detail below.

Table 3 shows the kinetic parameters for strain LLD15 when tryptone was removed from the complex medium. Although at $D=0.15$ and $0.2 \mathrm{~h}^{-1}$, cell yield and sucrose consumption were lower than in the medium with tryptone, these results indicated that $2 \mathrm{~g}$ yeast extract $1^{-1}$ alone sufficed to maintain good growth at $10 \mathrm{~g}$ sucrose $1^{-1}$.

Finally, the concentration of the yeast extract was reduced from $2 \mathrm{~g} \mathrm{l}^{-1}$ to $1 \mathrm{~g}^{-1}$. This resulted in a significant decrease of cell density and sucrose consumption (to $76.5 \%$ ), indicating that at this level the culture became limited by nutrients present in the yeast extract. Based on these results, it was assumed that at $10 \mathrm{~g}$ sucrose $1^{-1}$, the minimum concentration of yeast extract required was approximately $2 \mathrm{~g}^{-1}$ and that a synthetic medium with similar vitamin and amino acid composition would support anaerobic growth of strain LLD-15.

\section{Potential overgrowth by strain $L L D-R$}

At dilution rates above $0.3 \mathrm{~h}^{-1}$ in the medium containing $2 \mathrm{~g}$ yeast extract $1^{-1}$, that is at high specific rates of 
Table 4. Vitamin content of commercial yeast extracts and synthetic medium (BST-defined)

\begin{tabular}{lccccc}
\hline \hline & $\begin{array}{c}\text { Difco } \\
\left(\mu \mathrm{g} \mathrm{g}^{-1}\right)\end{array}$ & $\begin{array}{c}\text { Oxoid } \\
\left(\mu \mathrm{g} \mathrm{g}^{-1}\right)\end{array}$ & $\begin{array}{c}\text { At 2 } \mathrm{g} \text { yeast extract } \mathrm{1}^{-1} \\
\left(\mu \mathrm{g} \mathrm{I}^{-1}\right)\end{array}$ & $\begin{array}{c}\text { Published by } \\
\text { Rowe } \text { et al. (1975) } \\
\text { Kuhn } \text { et al. (1979) }\end{array}$ & BST-defined \\
\hline Thiamin & $3 \cdot 2$ & & $6 \cdot 4$ & 1000 & 1000 \\
Riboflavin & 19 & 150 & 300 & - & 450 \\
Nicotinic acid & 279 & 1250 & 2500 & 1000 & 1500 \\
Pyridoxine & 20 & & 40 & - & $450^{*}$ \\
Biotin & 1.4 & & $2 \cdot 8$ & 1000 & 1000 \\
\hline \hline
\end{tabular}

* Added as pyridoxal.

sucrose consumption $\left(q_{\mathrm{s}}\right)$, ethanol production dropped, and significant amounts of lactate were detected in the broth. The production of lactate at high $q_{\mathrm{s}}$ has also been observed with other thermophilic bacteria, such as Clostridium thermohydrosulfuricum (Germain et al., 1986). This has been attributed to the activation of $L-$ lactate dehydrogenase by an increase in the intracellular concentrations of fructose 1,6-diphosphate, a key intermediate of the glycolytic pathway.

In the case of strain LLD-15, it is more probable that lactate production represented take-over by the revertant strain LLD-R rather than a regulated response or overflow metabolism, as the process could not be reversed simply by returning to a lower dilution rate. Reversion of LLD-15 was not observed in early studies, but this is technically difficult to demonstrate on plates, and the enrichment of revertants in a single stage batch culture is probably too small to yield significant levels of lactate. Furthermore, it should be recognised that even if the reversion frequency was as low as $10^{-9}$ to $10^{-10}$, the cell population contained in the bioreactor (approx. $1.5 \times 10^{12}$ ) would still contain a reasonable number of revertant cells. Subsequent studies have confirmed that stable lactate-producing strains can be isolated from anaerobic continuous cultures growing at high $q_{\mathrm{s}}$.

At high $q_{\mathrm{s}}$ values, strain LLD-R might have taken over if the concentration of an intracellular metabolic intermediate in LLD-15 increased to toxic levels. It is likely that this toxicity was due to the accumulation of pyruvate, as a result of a rate-limiting step developing in pyruvate flow through the PDH or PFL pathways. The experimental observation that the extracellular pyruvate concentration increased prior to take-over by strain LLD-R supports this view. Strain LLD-R, on the other hand, can divert the excess pyruvate to lactate, and it therefore has a growth advantage over strain LLD-15 at high rates of sugar consumption.

\section{Formulation of a defined medium}

Table 4 shows the vitamin composition of commercial yeast extracts and the concentrations expected in a medium containing $2 \mathrm{~g}$ yeast extract $\mathrm{1}^{-1}$. Also shown is the medium used by Rowe et al. (1975) for the aerobic cultivation of B. stearothermophilus NCA 1503, and by Kuhn et al. (1979) for Bacillus caldotenax. Table 5 shows a similar analysis to determine the requisite levels of amino acids. Based on this analysis, a defined medium containing 18 amino acids and five vitamins was formulated. The amino acids L-asparagine and Lcysteine were not included, because they are present in minimal amounts in the yeast extract; the use of pyridoxal instead of pyridoxine was based on the work of Johnson et al. (1981).

\section{Identification of essential amino acids}

Preliminary batch experiments showed that it was possible to grow $B$. stearothermophilus strain LLD-15 anaerobically in the defined medium. Steady-state continuous cultures were then established, and the identification of essential amino acids using the pulse and medium-shift technique was initiated. The concentrations of amino acids in the incoming medium were reduced in steps to $50 \%, 25 \%, 12.5 \%$ and $6 \%$ of their initial levels, keeping the vitamin concentration constant.

Lactate production was observed whenever a medium shift caused a prolonged amino acid limitation $(20-30 \mathrm{~h}$ ), and sucrose accumulated in the bioreactor. This is shown in Fig. 1, where low levels of the essential amino acids serine and isoleucine limited the growth of strain LLD15 and caused an increase in residual sucrose. Each time lactate was detected in the bioreactor it was neccessary to restart the culture with strain LLD-15. It is probable that 


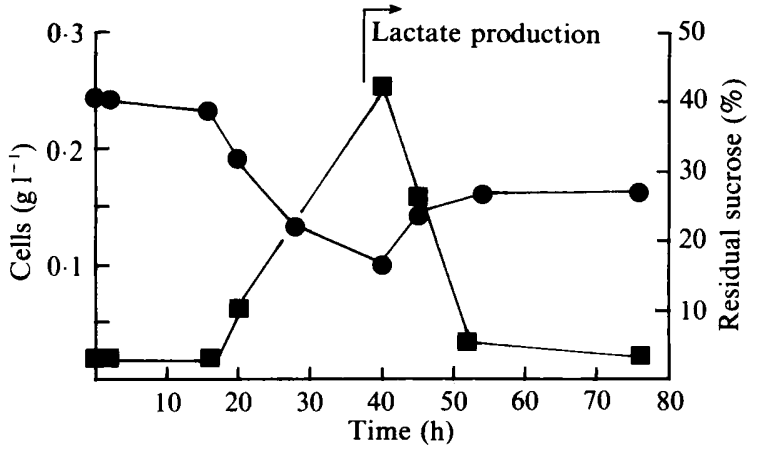

Fig. 1. Lactate production at $\mathrm{pH} 7 \cdot 0,70^{\circ} \mathrm{C}, 10 \mathrm{~g}$ input sucrose $\mathrm{l}^{-1}$ and $50 \%$ original amino acid composition of synthetic medium. Continuous operation on the diluted medium started at $4 \mathrm{~h}$. Limitation for serine and isoleucine caused the increase in residual sucrose concentration. , Cells; $\mathbf{0}$, residual sucrose.

reversion to lactate production resulted from an increase in the rate of sucrose consumption $\left(q_{\mathrm{s}}\right)$ as previously observed with increasing dilution rate. This could be the result of uncontrolled/poorly regulated uptake and

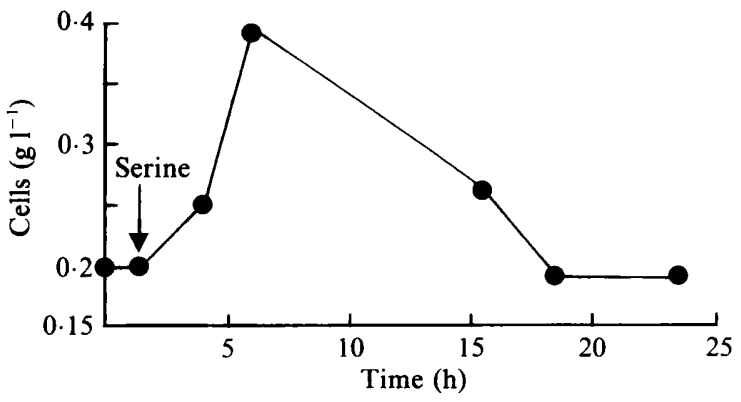

Fig. 2. Typical response of strain LLD-15 to the injection of an essential amino acid (serine). $D=0.1 \mathrm{~h}^{-1}, 70^{\circ} \mathrm{C}, \mathrm{pH} 7 \cdot 0,10 \mathrm{~g}$ input sucrose $1^{-1}$.

metabolism of excess sucrose, or the need to generate and maintain a large proton/ion gradient for transport of the limiting amino acid against a severe concentration gradient.

Fig. 2 illustrates a typical response of LLD-15 to the injection of an essential amino acid (serine) and Fig. 3 shows the response of LLD-15 to medium shifts and

Table 5. Amino acid composition of commercial yeast extracts and synthetic medium (BST-defined)

\begin{tabular}{|c|c|c|c|c|}
\hline & \multicolumn{2}{|c|}{ Commercial yeast extract } & \multirow[b]{2}{*}{$\begin{array}{l}\text { Published } \\
\left(\mathrm{mg} \mathrm{l}^{-1}\right)^{*}\end{array}$} & \multirow{2}{*}{$\begin{array}{l}\text { Synthetic medium } \\
\text { (BST-defined) } \\
\left(\mathrm{mg} \mathrm{l}^{-1}\right) \dagger\end{array}$} \\
\hline & $\underset{\left(\mathrm{mg} \mathrm{g}^{-1}\right)}{\text { Difco }}$ & $\begin{array}{c}\text { Yeatex } \\
\left(\mathrm{mg} \mathrm{g}^{-1}\right)\end{array}$ & & \\
\hline L-Alanine & - & $26 \cdot 5$ & 85 & 50 \\
\hline L-Arginine. $\mathrm{HCl} \ddagger$ & $7 \cdot 8$ & $6 \cdot 3$ & 60 & 15 \\
\hline L-Asparagine. $\mathrm{H}_{2} \mathrm{O}$ & - & - & 50 & - \\
\hline L-Aspartate & 51 & $37 \cdot 4$ & 130 & 100 \\
\hline L-Cysteine & - & trace & 50 & - \\
\hline L-Glutamate. $\mathrm{HCl} \|$ & - & $42 \cdot 0$ & 400 & 80 \\
\hline L-Glutamine & 65 & - & 50 & 130 \\
\hline Glycine & 24 & $20 \cdot 2$ & 50 & 50 \\
\hline L-Histidine. $\mathrm{HCl} \cdot \mathrm{H}_{2} \mathrm{O} \|$ & $9 \cdot 4$ & $8 \cdot 4$ & 40 & 20 \\
\hline L-Isoleucine & 29 & $17 \cdot 2$ & 100 & 60 \\
\hline L-Leucine & 36 & $25 \cdot 6$ & 160 & 70 \\
\hline L-Lysine. $\mathrm{HCl}$ & 40 & $25 \cdot 6$ & 140 & 80 \\
\hline L-Methionine $\|$ & 7.9 & $5 \cdot 5$ & 50 & 15 \\
\hline L-Phenylalanine & 22 & $13 \cdot 9$ & 85 & 50 \\
\hline L-Proline & - & $18 \cdot 5$ & 100 & 40 \\
\hline L-Serine $\|$ & - & $16 \cdot 4$ & 140 & 30 \\
\hline L-Threonine & 34 & 1.7 & 80 & 70 \\
\hline L-Tryptophan & 8.8 & $6 \cdot 3$ & 30 & 20 \\
\hline L-Tyrosine & 6 & $10 \cdot 9$ & 55 & 20 \\
\hline L-Valine $\S, \|$ & 34 & $21 \cdot 8$ & 130 & 80 \\
\hline Total (mg 1-1) & & & 1985 & 980 \\
\hline
\end{tabular}

* Based on Rowe et al. (1975) and Kuhn et al. (1979).

+ Based on composition of yeast extract added at $2 \mathrm{~g} \mathrm{l}^{-1}$

¥ Found growth-limiting for B. stearothermophilus NCA 1503 (aerobic cultivation) by Atkinson et al. (1975).

$\S$ Found similarly growth-limiting by Campbell \& Williams (1953).

|| Found similarly growth-limiting by Rowe et al. (1975). 


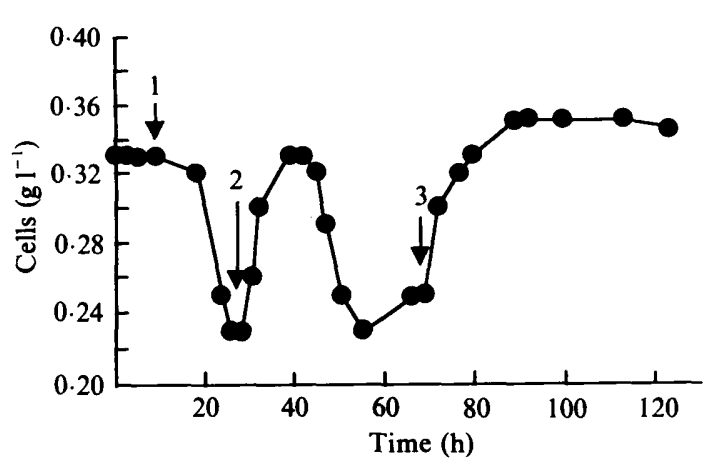

Fig. 3. Response of strain LLD-15 to medium shifts and injection of methionine. $10 \mathrm{~g}$ input sucrose $\mathrm{l}^{-1}, \mathrm{pH}=7.0,70^{\circ} \mathrm{C}, D=0.1 \mathrm{~h}^{-1}$. (1) Change of medium from $12.5 \% \mathrm{SM}+$ Ser and Ile $\left(150 \mathrm{mg} \mathrm{l}^{-1}\right)$ to $6 \%$ $\mathrm{SM}+$ Ser and Ile (150 $\left.\mathrm{mg} \mathrm{1}^{-1}\right)$, excluding Arg, His, Trp and Met, where SM is the original composition of synthetic medium containing 18 amino acids and five vitamins. (2) Injection of methionine. (3) Change to medium containing Met, Ile and $\operatorname{Ser}\left(150 \mathrm{mg} \mathrm{l}^{-1}\right.$ of each amino acid).

injection of methionine. Seven amino acids gave a positive response of varying intensity during the course of the pulse and medium-shift programme. Serine, isoleucine and histidine (slight) all gave a response at $50 \%$ dilution of the amino acids in the defined medium. Arginine, valine and glutamic acid all gave a slight response at $25 \%$, while methionine gave a strong response at $6 \%$. It is interesting to note that all of these amino acids had previously been reported to be essential for the aerobic cultivation of $B$. stearothermophilus strain NCA 1503, as shown in Table 5. However, Amartey et al. (1991) found that methionine was the only amino acid required for aerobic growth of LLD-15.

A continuous culture was initiated using the seven amino acids, and the growth kinetics of strain LLD-15 were studied at different dilution rates (results not shown). At $0 \cdot 2 \mathrm{~h}^{-1}$, cell yield and sucrose consumption were slightly higher than in the medium containing $2 \mathrm{~g}$ yeast extract $1^{-1}$ (Table 3 ). However, ethanol yields increased significantly (results summarised in Table 8) in relation to the complex medium, as discussed below. The amino acids that gave a slight response were sequentially removed from the medium (histidine, arginine, valine and glutamic acid). Only the removal of glutamic acid caused the cell density to drop significantly. Since glutamic acid was not required aerobically (Amartey $e t$ al., 1991), its requirement could be a response to the reduced activity of the oxidative arm of the TCA cycle under anaerobic conditions.

Starting with a medium containing vitamins, glutamate and the three remaining amino acids that gave a significant response (i.e. serine, isoleucine and methionine) the complete removal of each of these amino acids was shown to result in a drastic decrease in cell growth.
Table 6. Final composition of minimal medium BST-AMM

\begin{tabular}{lc}
\hline \hline Component & Concentration \\
\hline Main components $\left(\mathrm{g} l^{-1}\right)$ & 10 \\
Sucrose & 2 \\
$\mathrm{NH}_{4} \mathrm{Cl}$ & $0 \cdot 32$ \\
Citric acid & $0 \cdot 27$ \\
$\mathrm{MgSO}_{4} \cdot 7 \mathrm{H}_{2} \mathrm{O}$ & $2 \cdot 5$ \\
$\mathrm{Na}_{2} \mathrm{HPO}_{4}$ & $1 \cdot 3$ \\
$\mathrm{~K}_{2} \mathrm{SO}_{4}$ & \\
${\text { Other minerals }\left(m g l^{-1}\right)}_{\mathrm{CaCl}_{2} .2 \mathrm{H}_{2} \mathrm{O}}$ & $2 \cdot 5$ \\
$\mathrm{MnCl}_{2} .4 \mathrm{H}_{2} \mathrm{O}$ & $3 \cdot 0$ \\
Trace element solution $\left(m l l^{-1}\right)$ & $0 \cdot 25$ \\
Amino acids $\left(m g l^{-1}\right)$ & \\
Methionine & 150 \\
Isoleucine & 150 \\
Serine & 150 \\
Glutamic acid & 450 \\
Vitamins $\left(\mu g l^{-1}\right)$ & 1000 \\
Thiamin & 450 \\
Riboflavin & 1500 \\
Nicotinic acid & 450 \\
Pyridoxal & 1000 \\
Biotin & \\
\hline \hline
\end{tabular}

Removal of isoleucine caused cell lysis, and it was impossible to recover the culture even after readdition of the amino acid to the medium. As well as its function in proteins, isoleucine has been reported to be a precursor of low-melting-point fatty acids present in the membranes of some Bacillus species (Ljungdahl, 1979).

Amartey et al. (1991) reported that the only vitamins required for the aerobic cultivation of $B$. stearothermophilus strain LLD-15 were nicotinic acid, thiamin and biotin. An attempt to simultaneously remove pyridoxal and riboflavin proved unsuccessful. A delayed response to this medium-shift was observed, and the cell density dropped dramatically. Only after readdition of these vitamins to the reservoir did growth resume. However, pyridoxal and riboflavin were not removed individually, so it remains possible that one of these components is not essential. Based on these findings, Table 6 gives the composition of the final minimal medium (BST-AMM) containing four amino acids and five vitamins, and Table 7 indicates the behaviour of LLD-15 in this medium. All kinetic parameters were comparable with the medium containing seven amino acids indicating that, despite the initial indications, histidine, arginine and valine were not essential for anaerobic growth. Good ethanol productivities and sucrose consumption were possible up to $D=0.25 \mathrm{~h}^{-1}$, but above this level, lactate was detected in the broth. Also, the absence of anaerobic growth in BST-AMM without sucrose indicated that the amino acids were not being used as a primary carbon source by strain LLD-15. 
Table 7. Anaerobic cultivation of B. stearothermophilus LLD-15 at $70^{\circ} \mathrm{C}$ on a defined medium

Medium composition: $10 \mathrm{~g}$ input sucrose $\mathrm{I}^{-1}$; four amino acids, five vitamins, $\mathrm{pH}$ 7.0.

\begin{tabular}{|c|c|c|c|c|c|c|c|c|c|c|c|c|}
\hline \multirow[b]{2}{*}{$\underset{\left(h^{-1}\right)}{D}$} & \multicolumn{2}{|c|}{ Sucrose $\left(\mathrm{g}^{-1}\right)^{*}$} & \multirow[b]{2}{*}{$\begin{array}{c}\text { Sucrose } \\
\text { consumed }(\%)\end{array}$} & \multirow[b]{2}{*}{$\begin{array}{l}\text { Cells } \\
\left(\mathrm{g}^{-1}\right)\end{array}$} & \multirow[b]{2}{*}{$Y_{x / 8} \dagger$} & \multirow[b]{2}{*}{$\begin{array}{l}\text { Specific consumption } \\
{\left[\mathrm{g} \text { sucrose }(\mathrm{g} \text { cells })^{-1} \mathrm{~h}^{-1}\right]}\end{array}$} & \multirow[b]{2}{*}{$\left(\mathrm{g}^{-1}\right)$} & \multirow[b]{2}{*}{$\begin{array}{c}\text { Ethanol } \\
(\mathrm{mmol} \mathrm{1-1})\end{array}$} & \multirow[b]{2}{*}{$Y_{\mathrm{p} / 3} \ddagger$} & \multirow[b]{2}{*}{$Y_{1 / 2} \S$} & \multirow[b]{2}{*}{$\begin{array}{l}\text { Volumetric productivity } \\
\quad\left(\mathrm{g} \text { ethanol } \mathrm{1}^{-1} \mathrm{~h}^{-1}\right)\end{array}$} & \multirow[b]{2}{*}{$\begin{array}{l}\text { Specific productivity } \\
\text { [g sucrose }(\mathrm{g} \text { cells })^{-1} \mathrm{~h}^{-1} \text { ] }\end{array}$} \\
\hline & $\mathbf{S}_{0}$ & $\mathbf{S}_{1}$ & & & & & & & & & & \\
\hline 0.15 & 10.9 & 0.18 & 98.3 & 0.51 & 0.048 & $3 \cdot 1$ & 2.9 & 63.0 & $2 \cdot 0$ & - & 0.44 & 0.85 \\
\hline $0-20$ & 10.9 & 0.24 & 97.8 & 0.61 & 0.057 & $3 \cdot 5$ & 2.9 & 63.0 & $2 \cdot 0$ & - & 0.58 & 0.95 \\
\hline 0.25 & $10 \cdot 5$ & 0.31 & $97 \cdot 1$ & 0.60 & 0.059 & $4 \cdot 2$ & 2.6 & 56.5 & 1.9 & - & 0.65 & 1.08 \\
\hline 0.30 & 10.5 & 0.27 & $97 \cdot 3$ & 0.70 & 0.066 & $4 \cdot 6$ & 2.5 & $54 \cdot 4$ & 1.8 & 0.3 & 0.75 & 1.07 \\
\hline
\end{tabular}

- $\mathrm{S}_{0}$, sucrose concentration in incoming medium; $S_{1}$, residual sucrose concentration in bioreactor.

$\dagger Y_{\mathrm{x} / \mathrm{s}}, \mathrm{g}$ cells (g sucrose consumed) $)^{-1}$.

$\ddagger Y_{\mathrm{p} / \mathrm{s}}$, mol ethanol (mol sucrose consumed) ${ }^{-1}$.

$\S Y_{1 / s}$, mol lactate (mol sucrose consumed) ${ }^{-1}$.

Table 8. Comparison of complex and defined media for continuous cultivation at $70^{\circ} \mathrm{C}$ of B. stearothermophilus strain LLD-15 Conditions: $D=0.2 \mathrm{~h}^{-1} ; \mathrm{pH} 7 \cdot 0$.

\begin{tabular}{|c|c|c|c|c|c|c|c|}
\hline $\begin{array}{l}\text { Medium } \\
\text { composition* }\end{array}$ & $\begin{array}{c}\text { Sucrose } \\
\text { consumed }(\%)\end{array}$ & $\begin{array}{c}\text { Cells } \\
\left(\mathrm{g} \mathrm{I}^{-1}\right)\end{array}$ & $Y_{x / s} \dagger$ & $\begin{array}{c}\text { Specific consumption } \\
\text { [g sucrose }(\mathrm{g} \text { cells) })^{-1} \mathrm{~h}^{-1} \text { ] }\end{array}$ & $Y_{\mathrm{p} / \mathrm{s}} \ddagger$ & $\begin{array}{l}\text { Volumetric productivity } \\
\left(\mathrm{g} \text { ethanol } \mathrm{l}^{-1} \mathrm{~h}^{-1}\right)\end{array}$ & $\begin{array}{c}\text { Specific productivity } \\
\left.\text { [g ethanol }(\mathrm{g} \text { cells })^{-1} \mathrm{~h}^{-1}\right]\end{array}$ \\
\hline$a$ & $95 \cdot 1$ & 0.70 & 0.059 & 3.4 & 0.8 & 0.23 & 0.33 \\
\hline$b$ & 91.6 & 0.58 & 0.052 & 3.8 & 1.5 & 0.45 & 0.77 \\
\hline$c$ & 94.8 & 0.60 & 0.057 & 3.5 & $2 \cdot 2$ & 0.62 & 1.04 \\
\hline$d$ & 97.8 & 0.61 & 0.057 & $3 \cdot 5$ & $2 \cdot 0$ & 0.58 & 0.95 \\
\hline
\end{tabular}

- Compositions: $a, 2 \mathrm{~g}$ yeast extract $\mathrm{l}^{-1}$ plus $2 \mathrm{~g}$ Tryptone $\mathrm{l}^{-1} ; b$, as $a$ but no Tryptone; $c$, seven amino acids and five vitamins; $d$, four amino acids and five vitamins.

$\dagger Y_{\mathrm{x} / \mathrm{s}}, \mathrm{g}$ cells (g sucrose consumed) $)^{-1}$.

$\ddagger Y_{\mathrm{p} / \mathrm{s}} ;$ mol ethanol (mol sucrose consumed) $)^{-1}$.

Table 9. Fermentation products obtained in semi-defined aerobic medium (BST-SDLM; Amartey et al., 1991) and anaerobic minimal medium (BST-AMM) for continuous cultivation at $70^{\circ} \mathrm{C}$ of $B$. stearothermophilus strain LLD-15

Conditions: $D=0.2 \mathrm{~h}^{-1} ; 10 \mathrm{~g}$ sucrose $\mathrm{1}^{-1} ; \mathrm{pH} 7.0$.

\begin{tabular}{|c|c|c|c|c|c|c|c|c|}
\hline Medium & $Y_{\mathrm{x} / \mathrm{s}}^{*}$ & \multicolumn{6}{|c|}{ Yield [mol (mol sucrose consumed) $\left.)^{-1}\right]_{\dagger}$} & $\begin{array}{l}\text { Specific productivity } \\
{\left[\mathrm{g} \text { ethanol }(\mathrm{g} \text { cells })^{-1} \mathrm{~h}^{-1}\right]}\end{array}$ \\
\hline BST-SDLM & 0.05 & 1.3 & $3 \cdot 1$ & 1.5 & $0 \cdot 1$ & 0.1 & 0.1 & 0.4 \\
\hline
\end{tabular}

* $Y_{\mathrm{x} / \mathrm{s}}, \mathrm{g}$ cells (g sucrose consumed) ${ }^{-1}$.

† Abbreviations: EtOH, ethanol; For, formate; Ac, acetate; Succ, succinate; Pyr, pyruvate; Lac, lactate.

A final experiment showed that this medium was also suitable for aerobic cultivation of strain LLD-15, as expected (results not shown).

\section{Comparison of minimal, defined, semi-defined and complex media}

Table 8 compares the performance of the minimal media (four and seven amino acids) with media containing yeast extract and tryptone. Sugar consumption and cell density were comparable, but ethanol yields [mol EtOH (mol fermented sucrose) ${ }^{-1}$ ] increased upon the removal of the complex nutrients. This resulted in higher specific and volumetric ethanol productivities. A similar decrease in ethanol yields with increasing amounts of complex substances has been observed for Thermoanaerobium brockii (Lamed \& Zeikus, 1980).

Table 9 compares the product stoichiometries obtained in minimal medium with those in the semidefined medium previously developed for anaerobic growth, medium BST-SDLM, which contained $0.5 \mathrm{~g}$ yeast extract $1^{-1}$ and $0.5 \mathrm{~g}$ tryptone $\mathrm{1}^{-1}$ (Amartey et al., 1991). Product molar yields indicated that a higher proportion of the carbon flux passed through the PDH 
pathway in minimal medium than in the semi-defined medium, giving higher ethanol yields in the former. The observed yields of acetate and formate are a reflection of the activity of the PFL pathway and allow an estimation of the amount of ethanol formed by this route (Formate $=$ Acetate + Ethanol). Thus, with the semi-defined medium, it appears that most of the ethanol produced could be accounted for by the PFL pathway. However, when using the minimal medium, only $45 \%$ of the ethanol arose via the PFL pathway. The remaining $55 \%$ must therefore have been produced via the PDH pathway. Subsequent experiments with xylose have confirmed these results, and also have related the activity of the PDH pathway to $\mathrm{CO}_{2}$ production (San Martin, 1989). It should be noted that in the experiments reported here, all of the reported ethanol concentrations are underestimates, as no allowance has been made for losses in the vapour phase.

\section{Conclusions}

The pulse and medium-shift technique has successfully identified four amino acids and five vitamins as essential for anaerobic growth of LLD-15. It should be recognised that this technique involves definition of a medium at a predetermined growth rate. Thus, any component that is synthesized at a lower relative rate will be identified as a growth requirement, even though it may not be strictly essential. It is likely that the requirement for glutamate, a key intermediate in nitrogen metabolism and therefore in high demand, falls into this category. Furthermore, the initial observation of a requirement for arginine probably represented a 'sparing' effect on the use of glutamate, an immediate precursor of arginine. That is, the carbon flux to glutamate necessary for amino acid biosynthesis would be reduced by the provision of arginine. If this reduced flux could be met at the defined growth rate, but the higher flux in the absence of arginine could not, then arginine would give a positive response in this type of experiment. An anaerobic requirement for serine might also fall into the same category as glutamate, as the presumed branchpoint in serine biosynthesis (3-phosphoglycerate dehydrogenase) requires NAD as cofactor. In LLD-15, where one of the fermentation pathways is blocked, the NADH/NAD ratio is likely to be relatively high, thus reducing the flux through NAD-requiring steps.

Methionine was found to be a requirement for aerobic growth of LLD-15 (Amartey et al., 1991) so its anaerobic requirement was expected. However, the requirement for isoleucine is surprising and cannot readily be explained.

Utilization of sucrose was as high in the minimal medium as in the complex medium at all of the growth rates examined, with only a slight reduction in molar growth yield which was to be expected (Table 2 and Table 7). However, strict comparisons of cell densities at each dilution rate are difficult, because of the different fermentation pathways operating and their differing energy yields. Surprisingly, the proportion of carbon flux through the PDH pathway was significantly greater in the minimal medium than in complex medium (Table 9). There is no obvious metabolic explanation for this shift away from PFL. The rationale for induction of the PDH pathway under anaerobic conditions is that the excretion of acetate and formate produced by PFL becomes increasingly difficult as extracellular concentrations of these two acids increase and the protonated acid diffuses back into the cell. One explanation may be that cells growing in minimal medium are more sensitive to extracellular acetate and/or formate. This could result from a higher rate of diffusion back into the cells at equivalent extracellular concentrations, owing either to differences in cell physiology, or alternatively, to the loss of an anion-sequestering effect provided by the yeast extract and tryptone present in the complex medium. The latter would have the effect of reducing the apparent extracellular concentration of these acids.

R.S.M. is grateful to the British Council for financial support.

\section{References}

AMARTEY, S. (1988). Continuous ethanol production by a novel mutant thermophile from sucrose and pentoses. PhD thesis, Imperial College of Science, Technology and Medicine, London, UK.

Amartey, S., LeAK, D. J. \& HARTLEY, B. S. (1991). Development and optimization of a defined medium for aerobic growth of Bacillus stearothermophilus LLD-15. Biotechnology Letters 13, 621-626.

Atrinson, A., Evans, C. G. T. \& Yeo, R. G. (1975). Behaviour of Bacillus stearothermophilus grown in different media. Journal of Applied Bacteriology 38, 301-304.

BRock, T. D. (1978). Thermophilic microorganisms and life at high temperatures. Edited by M. P. Starr. Springer-Verlag: New York.

Campbell, L. L. \& Williams, O. B. (1953). The effect of temperature on the nutritional requirements of facultative and obligate thermophilic bacteria. Journal of Bacteriology 65, 141-145.

DRUmmond I. W. \& Shama, G. (1982). A rapid gas chromatographic method for the analysis of acidic fermentation products. Chromatographia 15, 180-182.

Dubois, M., Gilles, K. A., Hamilton, J. K., Rebers, P. A. \& Smith, F. (1956). Colorimetric method for determination of sugars and related substances. Analytical Chemistry 28, 350-356.

Germain, P., Toukourou, F. \& Donaduzzi, L. (1986). Ethanol production by anaerobic thermophilic bacteria: regulation of lactate dehydrogenase activity in Clostridium thermohydrosulfuricum. Applied Microbiology and Biotechnology 24, 300-305.

GoldBerG, I. \& ER-AL, Z. (1981). The chemostat - an efficient technique for medium optimization. Process Biochemistry 16, Oct/Nov, 2-8.

HaRTLEY, B. S. (1987). Thermophilic ethanol production. UK Patent Application 88-00411. 
HARTLEY, B. S. \& Shama, G. (1987). Novel ethanol fermentations from sugar cane and straw. Philosophical Transactions of the Royal Society A321, 555-568.

Johnson, E. A., Madia, A. \& Demain, A. L. (1981). Chemically defined minimal medium for growth of the anaerobic cellulolytic thermophile Clostridium thermocellum. Applied Environmental Microbiology 41, 1060-1062.

KaANan, V. \& MUTharasan, R. (1985). Ethanol fermentation characteristics of Thermoanaerobacter ethanolicus. Enzyme and Microbial Technology 7, 87-89.

KuHN, H., Friedrich, U. \& Fiechter, A. (1979). Defined minimal medium for a thermophilic Bacillus sp. developed by a chemostat pulse and shift technique. European Journal of Applied Microbiology and Biotechnology 6, 341-349.

LAMED, R. \& ZEIKUS, J. G. (1980). Glucose fermentation pathway of Thermoanaerobium brockii. Journal of Bacteriology 141, 1251-1257.

LJUNGDAHL, L. G. (1979). Physiology of thermophilic bacteria. Advances in Microbial Physiology 19, 149-243.

NG, T. G., Ben-Bassat, A. \& Zeikus, J. G. (1981). Ethanol production by thermophilic bacteria : fermentation of cellulosic substrates by cocultures of Clostridium thermocellum and Clostridium thermohydrosulfuricum. Applied and Environmental Microbiology 41, 1337-1343.
Payton, M. A. \& Hartley, B. S. (1985). Mutants of Bacillus stearothermophilus lacking NAD-linked L-lactate dehydrogenase. FEMS Microbiology Letters 26, 333-336.

Rowe, J. J., Goldberg, I. D., \& AMrlunXen, R. E. (1975). Development of defined and minimal media for the growth of Bacillus stearothermophilus. Journal of Bacteriology 124, 279-284.

SAN MARTIN, R. (1989). A high temperature continuous two-stage ethanol fermentation. PhD thesis, Imperial College of Science, Technology and Medicine, London, UK.

SONNLEITNER, B., FIECHTER, A. \& GiovanNini, F. (1984). Growth of Thermoanaerobium brockii in batch and continuous cultures at supraoptimal temperatures. Applied Microbiology and Biotechnology 19, 326-332.

VanCANNeyt, M., De Vos, P. \& De Ley, J. (1987). Ethanol production from glucose by Clostridium thermosaccharolyticum strains: effect of pH and temperature. Biotechnology Letters 9, 567-572.

WIEGEL, J., LJUNGDAHL, L. G. \& RAWSON, J. R. (1979). Isolation from soil and properties of extreme thermophile Clostridium thermohydrosulfuricum. Journal of Bacteriology 139, 800-810.

WIEGEL, J. \& LJUNGDAHL, L. G. (1981). Thermoanaerobacter ethanolicus gen. nov. spec. nov., a new extremely thermophilic, anaerobic bacterium. Archives of Microbiology 128, 343-348. 